The Journal of Public Space

2017 | Vol. 2 n. I

\title{
VIEWPOINT
}

\section{The public realm as a generator of urban design}

\section{Peter Richards}

Deicke Richards. Multi-disciplinary architecture \& design practice, Australia

peter@deickerichards.com.au

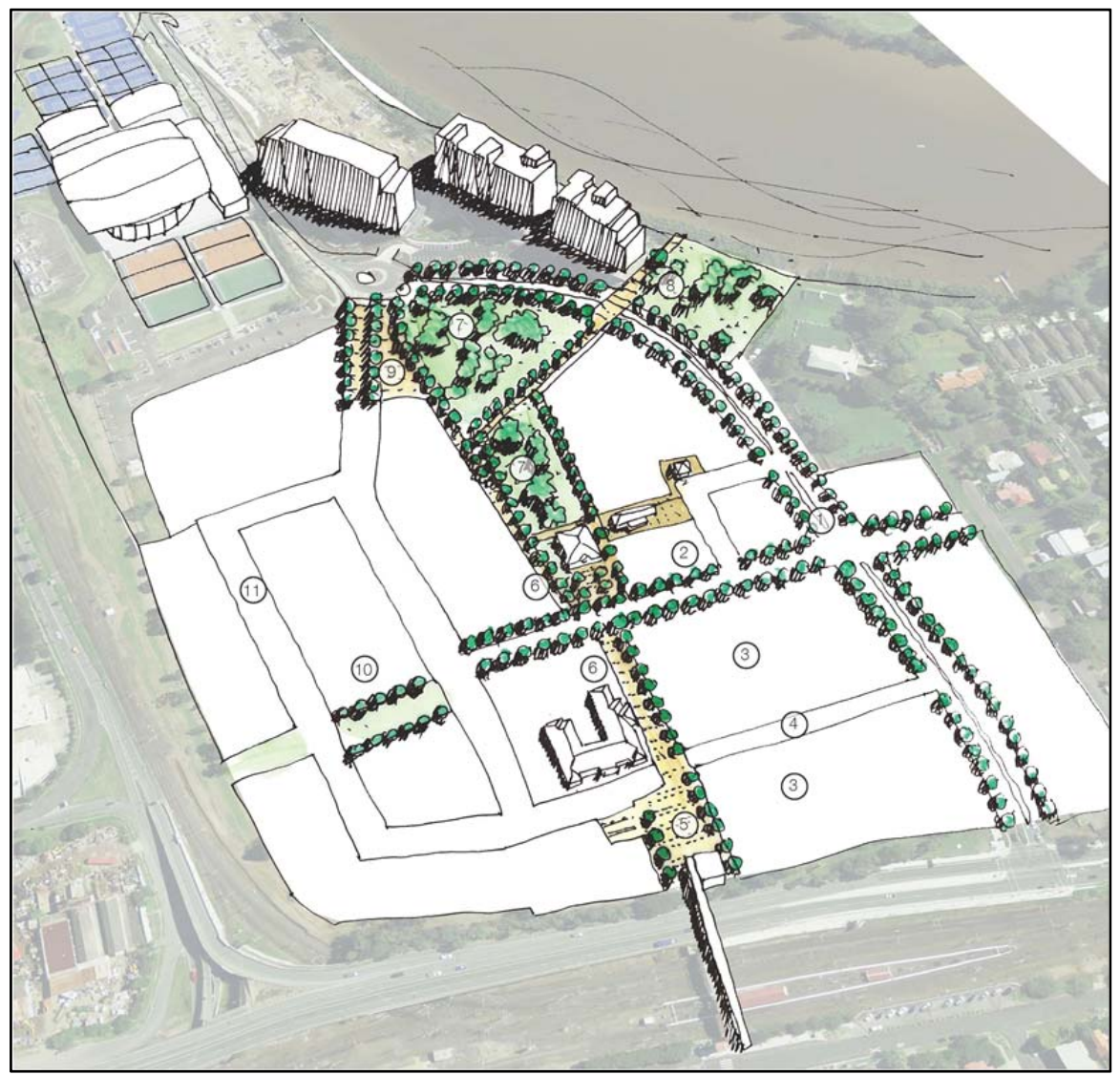

Fig. I. Yeerongpilly Green master plan, Brisbane, Australia. Deicke Richards, 20I0-20I4

For me, urban design at its heart is a positive activity that has a primary objective to contribute a public benefit. This is principally achieved by designing a network of public spaces - the public realm - that form the setting for individuals and communities to live their lives efficiently, safely, purposefully, meaningfully and memorably. The public realm consists of typical urban elements of streets, lanes, plazas, parks and environmental areas of different scales and purposes. These elements of public space are combined to create distinctive and unique places that invite use and activity. Underscoring this is the view that the primary user of public space is the pedestrian and the primary transport mode 
walking, cycling, and public transport. The car remains important but less so than the other modes.

With this approach, an essential requirement of the private realm of buildings is to form the public realm by positively defining public space, for it can't exist without the physical form of the buildings, and landscapes. The mix and location of land-uses in close proximity activate the public realm, so people can readily access the uses needed for daily life, and are invited to do so due to the quality of the urban setting.

These views have been formed, in part by analysis of the famous, and well-known Nolli Map of Rome, drawn in 1748. The first figure-ground drawing of an urban settlement, the Nolli Map shows the footprints of buildings in black, with streets, lanes and public spaces in white, along with some detail of gardens and landscape outlined. More importantly, it showed the interiors of public buildings as white - the same hierarchy as the outdoor spaces. Nolli saw the interiors of public buildings as public spaces, thus demonstrating the profound urban idea that the interior spaces of public buildings were public space, just as much as external spaces were. The power of the Nolli plan is in part of the plan that is not drawn with ink. The remaining spaces left in white are the public spaces comprising a rich sequence of streets, lanes and walkways of different widths and lengths, both straight and cranked, this is the public realm.

Through the years I have worked over this drawing. Firstly, by colouring the interiors of public buildings in black, then the public spaces, to leave the streets. This drawing showed the importance of connectivity, to make a seamless and integrated public realm, but connectivity on its own did not make a complete urban pattern. The open space fills were then removed showing the scale and disposition of open spaces. This gesture transformed the plan, giving it more order, clarity and legibility. The inclusion of these larger public spaces indicated places of gathering.

When the interiors of public buildings were removed, the richness of the plan and the drawing emerged. The public buildings showed the community life of the people of Rome through its institutions. Many of these public buildings were associated with major public squares or formed smaller plazas in prominent locations, sometimes on corners. The Nolli plan showed a seamless congruence of the private realm, with the public realm making a legible, remarkable and enduring urbanism. Rome effortlessly demonstrates how people can walk, meet, eat, drink, pause, reflect, catch some sun or celebrate personal and larger community events in a well-defined, coherent and legible public realm, positively defined by the buildings of the private realm. The white parts of the Nolli Plan show the public life in a public realm, the essential driver of urbanism.

In my work, I do not expect to emulate the urban quality of Rome, but these observations have informed my approach to urban design. A good example of where these ideas have been manifested is in the Yeerongpilly Green master plan for the city of Brisbane in Australia, undertaken by my practice Deicke Richards from 2010 to 20I4. The site was about 13 hectares in size and would accommodate more than 1,000 residences with related retail and commercial activities.

The Yeerongpilly Green site is a strategically located riverfront brownfield site, an old animal research station dating from 1909, approximately 10 kilometres from the centre of Brisbane. The site is relatively isolated, bounded on the east by an arterial, Fairfield Road and a railway line containing the Yeerongpilly Station - about 25 minutes travel to the city 
centre. There are no street connections to the residential areas east of the station. To the south a rail freight line forms another barrier, with industrial uses beyond. An established low-density residential area is located north of the site.

To the west of the site is a former disused power station that has been recently developed into the State Tennis Centre, which wished to expand into the Yeerongpilly Green site. As part of this development, three large and long residential apartment buildings were constructed fronting the Brisbane River, forming a formidable barrier to any development immediately behind. At the end of the apartments, a small, open space about $40 \mathrm{~m}$ wide, was left and this was the only location where Yeerongpilly Green could connect to the river. When the tennis centre was developed, a street from the west, King Arthur Terrace, was extended through the site to Fairfield Road to enable access from the west and east to the tennis centre and the apartments. However, the street had a broad sweep in it, causing it to be uninviting, less accessible for traffic and consequently less legible. In addition, a pedestrian bridge was built over Fairfield Road connecting the station to the tennis centre making a pedestrian desire line through the Yeerongpilly Green site.

Four heritage buildings, including two research buildings, a stable and an animal morgue needed to be retained. While well setback from the street, both research buildings had frontages to and views from Fairfield Road, as this was their original setting. To add to the complexity, the local council decided to build a new and significantly sized local office early in the design process. These circumstances of the project have fundamentally influenced the design and the extent and character of the public realm, which are described as follows and shown on Fig. I.

I. King Arthur Terrace was straightened from its broad sweeping curve to improve legibility, enable more efficient and regular block sizes, and improve the urban character of the entrance to the precinct. This was slightly controversial as the winding street was recently constructed.

2. The retail based mixed-use main street ran north-south from King Arthur Terrace and was placed between the two larger heritage buildings creating the central focal place or heart of the precinct. This put the main street about $150 \mathrm{~m}$ from Fairfield Road, aligning it with a residential street to the north, suggesting an integration of these residential areas with the heart of the new precinct.

3. This grid layout enabled larger blocks to be formed on the corner of the most important streets in the precinct, which could then accommodate large format retail on the Main Street, and offices facing Fairfield Road with the associated car parking.

4. A service lane between the lots facing Fairfield Road and the main retail block provided service access to both lots keeping services and the large car generating uses away from the more residential areas of the design. It also enabled the main street further west not to require any service access along it.

5. A sequence of open spaces provided pedestrian connectivity from Fairfield Road to the Tennis Centre and river. A plaza on Fairfield Road created an arrival place for the over-bridge and maintained the historical setting of both the heritage buildings to the street, but with framed views rather than expansive views.

6. This sequence of spaces extended as a walkway past the first heritage building to the main street then formed a plaza on this street in front of the earliest research 
building that terminated the vista from Fairfield Road. This plaza extended northward, to integrate the stable and morgue.

7. The open space network continued past the heritage buildings as a wider park, which opened out to the tennis centre and helped with flooding and storm water management. Pedestrian walkways edged the park space along development frontages. The southern walkway connected to the Tennis Centre and the northern route angled towards the river.

8. The northern walkway turned to the north and connected to the open space near the river, which became a riverside park.

9. The southern walkway continued to an arrival plaza for the future tennis centre expansion.

10. The main street extended southward and connected to a green space / community garden which acted as a focal place of the residential precinct. An open space was left in the blocks along the southern boundary to enable future pedestrian linkages if desired.

II. Other streets ran east west where possible to enable greater orientation to the north, the desired orientation in South East Queensland.

The Yeerongpilly Green Master Plan was formed on a fundamental idea that the public realm is the generator of the design. The land uses were located in appropriate locations to support and activate the public realm. Since the master plan was completed in 2014, the site has been put to market. The successful developer is effectively implementing the master plan with a number of refinements, so the unique and distinctive public realm conceived for this project may well be realised.

\section{To cite this article:}

Richards, P. (2017). The public realm as a generator of urban design, The Journal of Public Space, 2(I), I53-I56, DOI: 10.5204/jps.v2il.58

This article has been accepted for publication in The Journal of Public Space. Please see the Editorial Policies under the 'About' section of the journal website for further information. 